$\xi=-1$

\title{
The Influence of Land Use Change and Spatial Discretization of Middle - Lower Ciliwung Sub-Watershed on Flood Hydrograph at Manggarai Weir : a Preliminary Study
}

\author{
Nonik Eko Wahyuning Tiyas**1, Dwita Sutjiningsih ${ }^{2}$ \\ ${ }^{1}$ Postgraduate Student in Civil Engineering Department, Faculty of Engineering, Universitas Indonesia, Indonesia \\ ${ }^{2}$ Lecturer in Civil Engineering Department, Faculty of Engineering, Universitas Indonesia, Indonesia ffiliation of the second author \\ *Corresponding author E-mail: nonik.ewt28@gmail.com
}

\begin{abstract}
Jakarta is a lowland area with $40 \%$ of its territory at an elevation below the sea level so it is very vulnerable to flooding. One of out many causes floods in Jakarta is by the overflow of the Ciliwung River. The Ciliwung Watershed has a very strategic value in Indonesia because the Ciliwung River is one of thirteen rivers crossing the nation's capital. The rapid urbanization and population growth led to an increasing impervious area in the Ciliwung Watershed which resulted in a flood hydrograph change. This research aims to determine the influence of land use change, which is taking into account the spatial discretization and the riparian characteristic of Middle - Lower Ciliwung Sub-Watershed on flood hydrograph at Manggarai Weir. This research reviews the related literature on the implementation of HEC-GeoHMS version 10.1 developed by US Army Corps of Engineers (2013) to estimate the effect of land use change on flood hydrographs by taking into account the characteristics of the riparian described descriptively and present arguments to claim that the discretization spatial method can provide significantly more flood hydrographs results with existing conditions.
\end{abstract}

Keywords: HEC-GeoHMS; land use change; riparian characteristics, spatial discretization

\section{Introduction}

According to Masterplan for Drainage and Flood Control of Jakarta (1) Ciliwung watershed approximately has $347 \mathrm{~km} 2$ in area and the length of its main river is $117 \mathrm{~km}$. Based on the toposequences, Ciliwung watershed is divided by three parts which are upstream, middlestream and downstream. As a watershed ecosystem, changes that happen in the upperstream could affect the whole area. The main city that located in the downstream area become the reason for it to be strategically valuable for the development and management of area around downstream (2).

As a hydrological system, the upstream area play the function of protecting the whole area of watershed, while the middle and downstream area is the area for utilization. Flood is happening because of the changes and unappropriate management system for landuse, while landuse changes is dynamically flexible to the water flow discharge as a respon to the total rain water (3). Thus flooding management control in the watershed area and spatial planning are important factors that needed to be done.

Changes in land use in the Ciliwung watershed from green area to impervious areas greatly affect the flow of the Ciliwung River. In the Middle Ciliwung sub-watershed, most of which are the buffer zones of Jakarta's capital city also experienced an increase in the impervious area due to the growing residential area. The impact of the increasing impervious area is the occurrence of a flood hydrograph magnitude at the Manggarai Weir, Jakarta. Flooding are very sensitive to the changes in land use and unappropriate land management.
Some of the studies show that the increasing magnitude of flooding in Ciliwung watershed caused by unappropriate management system in the upstream area. In 1981-1999, the landuse of upstream area has been changing 14.860 ha (4), and the other research states that landuse changes create an impact in increasing the water discharge in the upstream area around $65 \%$ and increasing in the flooding volume until $50 \%$ (5). The contribution of water run-off from the upstream and the middle stream area are predicted around $42.44 \%$, while in the downstream area is $57.56 \%$ ) (6).

Based on data compiled by the Ministry of Environment on the Ciliwung River Profile (2010), the ecological conditions of the Ciliwung watershed are very alarming, as reflected in the decline in forest cover from $9.4 \%$ in 2000 to $2.3 \%$ in 2010 , or experiencing an environmental degradation rate of $7.14 \%$ over the last 10 years $(0,7 \%$ per year $)(7)$.

The riparian condition will be done to find out the roughness coefficient. Natural riparian has a high roughness coefficient, so the velocity is also small. The riparians that have turned into concrete have small roughness coefficient to accelerate the flow to downstream.

In hydrological modeling, a watershed is treated as a number of small homogeneous units to overcome spatial heterogeneity resulting from the variability of physical processes and physical characteristics in a watershed (8). This spatial heterogeneity is often associated with an unequal distribution of hydrological properties along the watershed. The spatial discrete process, in which we separate a watershed into homogeneous computing units for metaphor in the hydrological model, is really an attempt to determine how to characterize inherent spatial heterogeneity found in a watershed. 
Spatial discretization should be sufficiently detailed to capture dominant processes and natural variability, while also needing to be as short as possible to save computation time and data availability. A very detailed spatial discritization increases the complexity of the model (ie, the number of computing units) and thus increases the computation time of the model. However, too coarse aggregation can lead to substantial loss of information and increase model's structural uncertainty, whose impact on hydrological prediction is much worse than data parameters and uncertainties.

HEC-GeoHMS is a geospatial hydrological tool designed to prepare data for HEC-HMS simulations. The program allows users to visualize spatial discretization information, document watershed characteristics, perform spatial analysis, describe subbasins and streams, build inputs for hydrological models and assist with report preparation. HEC-GeoHMS creates an input file that can be used for HEC-HMS simulation. To help estimate hydrological parameters, HEC-GeoHMS can generate tables containing the physical characteristics of streams.

This research aims to determine the influence of land use change and spatial discretization of Middle - Lower Ciliwung SubWatershed to hydrograph at Manggarai Weir. This research will identify land-use changes at Ciliwung Watershed by ArcGIS version 10.1, delineat the Sub-Watershed and then using HECGeoHMS software version 10.1 developed by the US Army Corps of Engineers (2013) (9) to find out how the effect of land-use change and account the characteristics of the riparian of the Ciliwung River.

\section{Literature Review}

\subsection{Average Rainfall}

This method gives specific weight to each rain station with the sense that each rain station is considered to represent rain in a certain area, and that extent is a weighting factor for rain.

$$
\begin{aligned}
& C=\frac{A i}{A_{\text {total }}} \\
& \bar{R}=\frac{A_{1} R_{1}+A_{2} R_{2}+\ldots+A_{n} R_{n}}{A_{1}+A_{2}+\ldots+A_{n}}
\end{aligned}
$$

Where :

$$
\begin{array}{lll}
\mathrm{C} & : & \text { Thiessen coefficient } \\
\mathrm{Ai} & : & \text { area of influence from observation station } \mathrm{i} \\
\mathrm{A} & : & \text { Area of watershed } \\
\overline{\mathrm{R}} & : & \text { average rainfall } \\
\mathrm{R} 1, \mathrm{R} 2, . ., \mathrm{Rn} & : & \text { rainfall data }
\end{array}
$$

\subsection{Rainfall Distribution}

If extreme rainfall data is not obtained, daily data can be used in the existing watershed measurement of discharge with the same period and rain distribution pattern obtained from short duration rainfall (10).

Table 1: Rainfall Distribution Pattern

\begin{tabular}{|c|c|c|c|c|c|c|c|c|c|}
\hline $\begin{array}{l}\text { Rain } \\
\begin{array}{l}\text { Pat- } \\
\text { terns } \\
\text { (hours) }\end{array}\end{array}$ & $\mathbf{1}$ & $\mathbf{2}$ & $\mathbf{3}$ & $\mathbf{4}$ & $\mathbf{5}$ & $\mathbf{6}$ & $\mathbf{7}$ & $\mathbf{8}$ & $\begin{array}{c}\text { Inter- } \\
\text { val }\end{array}$ \\
\cline { 2 - 10 } & & & & & & & & \\
\hline 3 & 68 & 24 & 8 & & & & & & 1 \\
\hline 4 & 26 & 61 & 10 & 3 & & & & & 1 \\
\hline 5 & 11 & 54 & 28 & 6 & 1 & & & & 1 \\
\hline 6 & 12 & 54 & 24 & 6 & 3 & 1 & & & 1 \\
\hline 7 & 50, & 25, & 12, & 6, & 3,4 & 1, & 0, & & 1 \\
\hline 8 & 5 & 5 & 6 & 5 & 2 & 3 & & 1 \\
\hline
\end{tabular}

\subsection{Rainfall Plan}

The measurement of dispersion is to measure the degree or magnitude of the variant around its mean value. The way of measurement of dispersion are:

a. Standard Deviation (S)

$S=\sqrt{\frac{\sum_{i=1}^{n}\left(X_{i}-\bar{X}\right)^{2}}{n-1}}$

Where :

$\mathrm{S} \quad$ : standard deviation

$\overline{\mathrm{X}} \quad$ : average rainfall

$\mathrm{X}_{\mathrm{i}}$ : the measurement value of rainfall

$\mathrm{n} \quad$ : amount of rainfall data

b. Variation Coefficient $\left(\mathrm{C}_{\mathrm{v}}\right)$

$C_{v}=\frac{S}{\bar{X}}$

Where :

$\mathrm{C}_{\mathrm{v}} \quad$ : variation voefficient

$\overline{\mathrm{X}} \quad$ : average variant

$\mathrm{S} \quad$ : standard deviation

c. Skewness Coefficient $\left(\mathrm{C}_{\mathrm{s}}\right)$

$C_{S}=\frac{n \sum_{i=1}^{n}\left(X_{i}-\bar{X}\right)^{2}}{(n-1)(n-2) S^{3}}$

Where :

$\mathrm{C}_{\mathrm{s}} \quad$ : skewness coefficient

$X_{i}$ : the value of variant

$\overline{\mathrm{X}} \quad$ : average variant

$\mathrm{n} \quad$ : amount of rainfall data

$\mathrm{S} \quad$ : standard deviation

d. Kurtosis Coefficient $\left(\mathrm{C}_{\mathrm{k}}\right)$

$C_{k}=\frac{\frac{1}{n} \sum_{i=1}^{n}\left(X_{i}-\bar{X}\right)^{4}}{S^{4}}$

Where :

$\mathrm{C}_{\mathrm{k}} \quad$ : Kurtosis Coefficient

$\mathrm{n} \quad$ : amount of rainfall data

$X_{i} \quad$ : the measurement value of rainfall

$\overline{\mathrm{X}} \quad$ : average rainfall data

$\mathrm{S} \quad$ : standard deviation

Table2: Distribution Terms

\begin{tabular}{|c|l|c|}
\hline No. & Distribution & Terms \\
\hline 1 & \multirow{2}{*}{ Normal } & \%Variat $1=68,27 \%$ \\
\cline { 3 - 3 } & & \%Variat $2=95,44 \%$ \\
\cline { 3 - 3 } & & $\mathrm{Cs} \approx 0$ \\
\cline { 3 - 3 } & & $\mathrm{Ck} \approx 3$ \\
\hline 2 & \multirow{2}{*}{ Log-Normal } & $\mathrm{Cs}=\mathrm{Cv}^{3}+3 \mathrm{Cv}$ \\
\hline 3 & & $\mathrm{Ck}=\mathrm{Cv}^{8}+6 \mathrm{Cv}^{6}+15 \mathrm{Cv}^{4}+16 \mathrm{Cv}^{2}+3$ \\
\hline & Gumbel & $\mathrm{Cs} \leq 1.14$ \\
\hline 4 & Log-Pearson Type III & $\mathrm{Ck} \leq 5.4$ \\
\cline { 3 - 3 } & & $\mathrm{Cs}<0$ \\
\hline
\end{tabular}

Source: (11)

\subsection{Gumbel Distribution}

Gumbel distribution is an extreme value distribution, in flood discharge analysis is generally used for maximum data analysis, 
for example for frequency analysis or flood return period. The function of the Probability Density Function of Gumbel distribution is:

$$
P(X \leq)=e^{-e^{-Y}} \text { with }-\infty<X<+\infty
$$

Where :

$$
\begin{array}{ll}
P(X \leq x) & \text { Probability Density Function } \\
\mathrm{X} & : \text { continuous random variable } \\
\mathrm{e} & : 2,71828 \\
\mathrm{Y} & : \text { Gumbel reduction factor }
\end{array}
$$

To calculate the rainfall plan with Gumbel distribution method used empirical frequency distribution equation as follows (12) :

$$
\begin{aligned}
& X_{T}=\bar{X}+\frac{S}{S_{n}}\left(Y_{T}-Y_{n}\right) \\
& S=\sqrt{\frac{\sum\left(X_{i}-\bar{X}\right)^{2}}{n-1}}
\end{aligned}
$$

The relationship between return period $\mathrm{T}$ and $\mathrm{Y}_{\mathrm{T}}$ can be calculated by the formula:

for $\mathrm{T} \geq 20 \rightarrow \mathrm{Y}=\ln \mathrm{T}$

$$
Y_{T}=-\ln \left\{-\ln \frac{T-1}{T}\right\}
$$

Where :

$\mathrm{X}_{\mathrm{T}}$ : rainfall value of plan with year $\mathrm{T}$ measurement data

$\overline{\mathrm{X}} \quad$ : average rainfall

$\mathrm{S}$ : standard deviation

$\mathrm{Y}_{\mathrm{n}} \quad$ : reduce mean, the value depends on the amount of data (n)

$S_{n}$ : reduced standart deviation, the value depends on the amount of data (n)

$\mathrm{Y}_{\mathrm{T}}$ : reduced variate of the expected variable occurs in the $\mathrm{T}$ year return period.

\subsection{Riparian Characteristics}

Riparian is the space between the edge of the riverbed and the inner embankment lying on the left and / or right of the river. The line of the riparian is the virtual line on the left and right of the riverbed defined as the boundary of river protection. This research identifies the riparian conditions of the Ciliwung River in the main river channel for flood tracking purposes by taking into account the coefficient of roughness (n) Manning which is influenced by the riparian condition. To determine the value of $n$ Manning (13), the following equations are used:

$\mathrm{n}=\left(\mathrm{n}_{0}+\mathrm{n}_{1}+\mathrm{n}_{2}+\mathrm{n}_{3}+\mathrm{n}_{4}\right) \mathrm{m}$

Where :

$\mathrm{n}$ : coefficient value of channel roughness

$\mathrm{n}_{0}$ : roughness coefficient value based on channel material arrangement

$\mathrm{n}_{1}$ : roughness coefficient value value based on river flow irregularity

$\mathrm{n}_{2}$ : roughness coefficient value based on cross sectional variation (shape and size)

$\mathrm{n}_{3}$ : roughness coefficient value based on obstacle / flow barrier

$\mathrm{n}_{4}$ : roughness coefficient value based on vegetation conditions

$\mathrm{m}$ : meandering

\subsection{HEC-GeoHMS Hydrologic Model}

Geographic Information System (GIS) is a component consisting of hardware, software, geographic data and human resources working together effectively to enter, store, repair, managing, manipulating, integrating, analyzing and displaying data in a geographically based information. GIS capabilities are used to format data, process, and perform coordinate transformations. GIS helps in obtaining spatial hydrological data, such as Digital Elevation Model (DEM), soil type, land use, rainfall, etc. Then HECGeoHMS will process DEM generated by GIS and enable users to visualize spatial information, document the characteristics of a watershed, perform spatial analysis, and describe subcatchments0020 (9). Data processing using HEC-GeoHMS model is divided into 3 parts, namely:

1. Terrain Preprocessing

In this process field data is used as input. The terrain data is DEM. In this process field data is processed and analyzed and derived into additional datasets, namely: DEM Reconditioning, Flow Direction, Flow Accumulation, Stream Definition, Stream Segmentation, Grid Delineation Catchment, Polygon Catchment, Drainage Line, Adjoint Catchment, Drainage Point. In the Stream Definition stage will initiate the process of spatial discretization in the form of division of stream threshold in accordance with alternative scenarios to be analyzed.

2. Basin Processing

This process is done to obtain the characteristics of watershed by processing the Terrain Preprocessing result map. From this process we will get the characteristics of watershed in the form of: river length, river slope, slope of watershed, $\mathrm{CN}$ value. At this stage, export map to HMS unit is generated by generating HMS Link and HMS Node. At this stage also begin to be made schematic Basin Model which will then be exported as background in HEC-HMS simulation.

3. Modeling HEC-HMS

Prior to entry in the process of using HEC-HMS, several hydrological parameters, in addition to the physical characteristics of rivers and subbasins, shall be determined.

a. Determining CN Value

CNGrid can be made using HEC-GeoHMS with input data of land use type, hydrological soil group, along with lookup table (CNLookUp).

b. Preparing Rainfall Data

By using rainfall data from several rain stations it is necessary to see the influence of each rain station on watershed and Middle Ciliwung sub watershed up to Manggarai Weir. To determine the influence of each rain station is used Polygon Thiessen method with the help of ArcGIS.

c. Selecting HEC-HMS Process

In this research the method used is SCS method for Loss and Transform Method on Subbasin and Kinematic Wave for Route Method on River.

d. HEC-HMS Simulation

Parameters that have been processed in the previous stages will be exported so that it can be used as parameters in the HEC-HMS model. By exporting data that has been prepared can occur directly in HEC-HMS. In this step the process will be carried out with the HEC-HMS hydrological model. Due to the use of HEC-GeoHMS, the parameters required to run the HEC-HMS model are occupied, among them the basin model (area, loss and transform method, CN sub-basin, and sub-basin lagtime) and meteorologic model (data input precipitation) using a specified hyetograph.

e. Calculation of Model Accuracy

To determine the predictive accuracy of the HECGeoHMS model, the outcome of the model was compared with field observation data. To determine the accuracy of 
the model, the efficiency coefficient of Model (E) NashSutcliffe was used. This method is commonly used to assess the prediction accuracy of the hydrological discharge model.

$$
E=1-\frac{\sum_{i=1}^{n}\left(X_{o b s, i}-X_{\text {model }}\right)^{2}}{\sum_{i=1}^{n}\left(X_{o b s, i}-\overline{X_{o b s}}\right)^{2}}
$$

Where :

$\begin{array}{ll}\mathrm{X}_{\text {obs }} & : \text { the value observed at time } \mathrm{i} \\ \mathrm{X}_{\text {model }} & :\end{array}$

Nash-Sutcliffe efficiency value can range from $-\infty$ to 1 . If the result shows efficiency value $1(\mathrm{E}=1)$ then it can be concluded that the model results in accordance with the results of observation. If the efficiency value is $0(\mathrm{E}=0)$, then this indicates that the model prediction is closer to the average observation data. While the result less than $0 \quad(-\infty<\mathrm{E}<0)$ indicates that the average observation result is better than the result of the hydrological model. So in other words, the value of the efficiency of the model close to 1 then the results issued more accurate model.

\section{Materials \& Methodology}

\subsection{Materials}

This research used the following data:

1. Rainfall data from some meteorogical stations at Ciliwung Watershed (Gadog, Cibinong, FTUI, Cawang) on 2008 - 2017

2. Spatial data : topographic map scale 1:25.000 or Digital Elevation Model (DEM) obtained from Badan Informasi Geospasial (BIG) covering the Ciliwung Watershed.

3. Soil map at Ciliwung Watershed.

4. Land use map in 2017 at Ciliwung Watershed.

5. Land use map according to Regional Land Use Plan of Bogor Regency, Bogor City, Depok City and Jakarta Province.

6. Water level data record from Katulampa Dam and Manggarai Weir in 2017.

7. Rating curve of Katulampa Dam and Manggarai Weir.

8. Cross section data and riparian data from section Katulampa Dam to Manggarai Weir.

\subsection{Framework Study}

This research was conducted through several stages including :

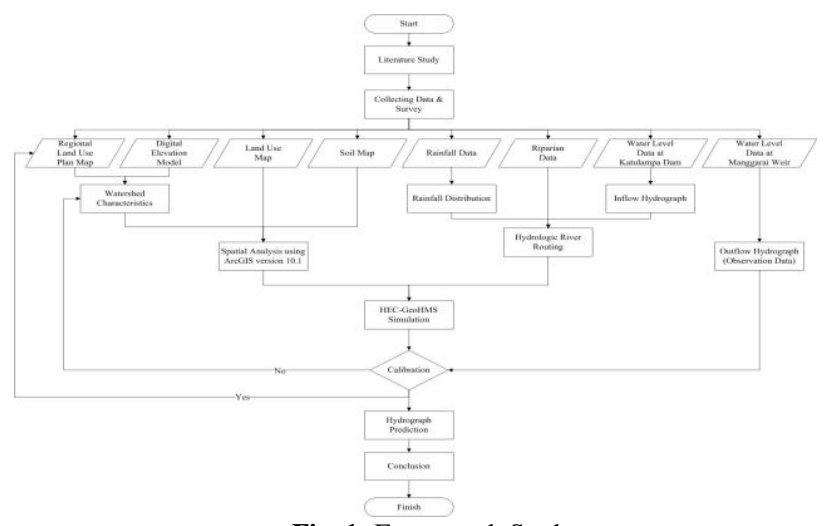

Fig. 1: Framework Study

\section{Result and Findings}

\subsection{Spatial Data Processing}

The first step is to process the main data in the form of spatial data (Digital Elevation Model/DEM).

\subsection{Spatial Data Processing}

Alternative scenarios to be analyzed are determined as follows:

1. Scenario 1 - stream threshold $174,39 \mathrm{~km}^{2}$ (area of Middle Ciliwung sub-watershed to Manggarai Weir)

2. Scenario 2 - stream threshold $25 \mathrm{~km}^{2}$

3. Scenario 3 - stream threshold $15 \mathrm{~km}^{2}$

\subsection{Determining Curve Number $(\mathrm{CN})$ Value}

The data required are 2017 land use map, soil map, and $\mathrm{CN}$ value table. To facilitate the identification of $\mathrm{CN}$ values on subwatersheds, an overlay is made on ArcGIS land use maps, soil types and $\mathrm{CN}$ tables that have been created in the form of a CNlookup table. From the overlay will produce a CNGrid map that can be used to determine the $\mathrm{CN}$ value in each sub watershed.

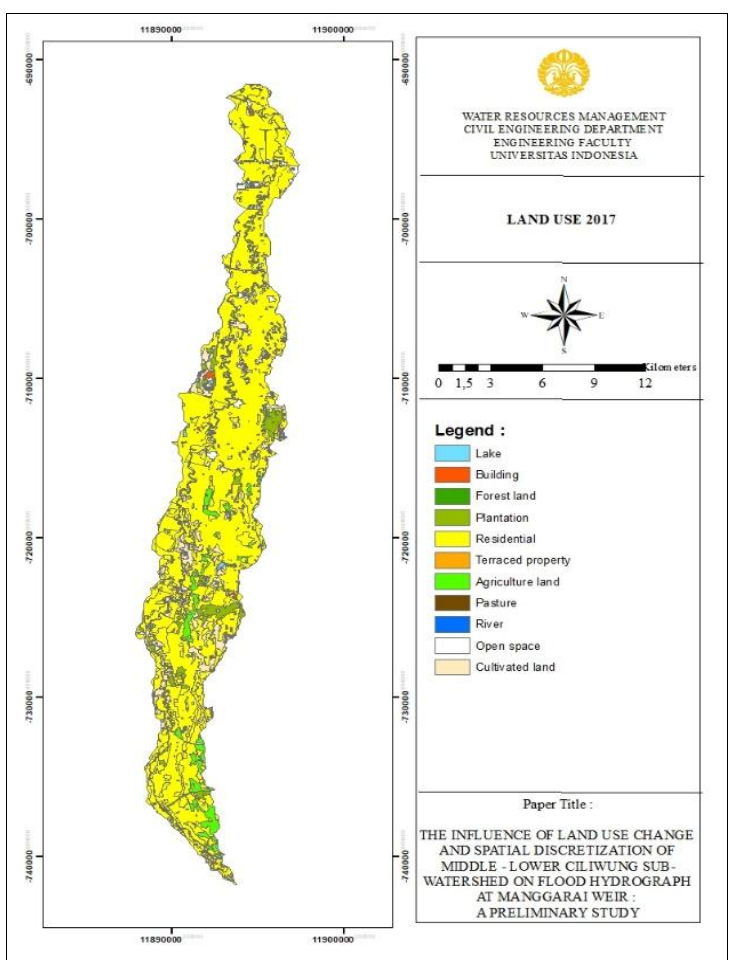

Fig. 2: Land Use 2017

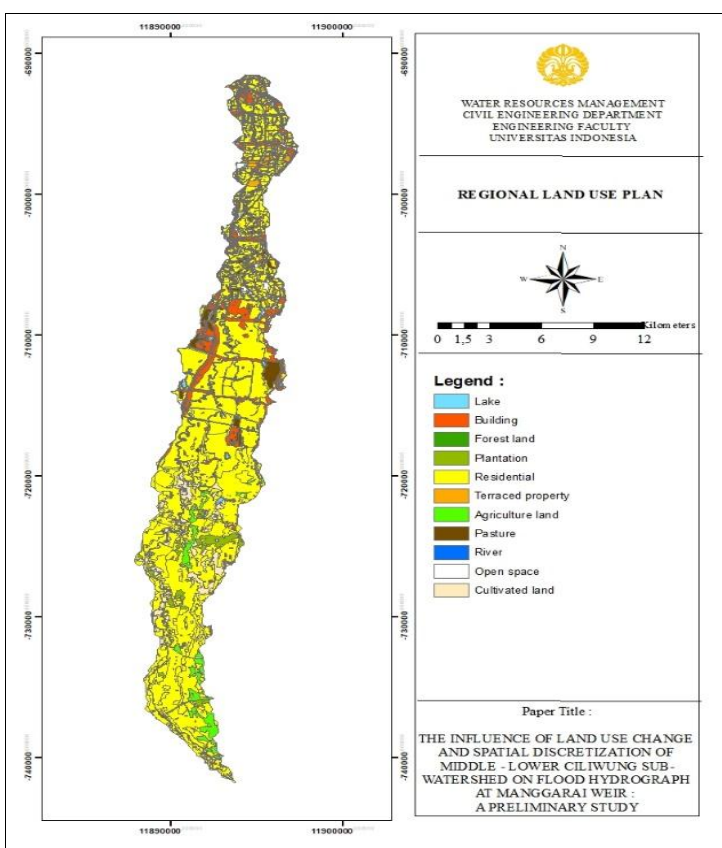

Fig. 3: Regional Land Use Plan 


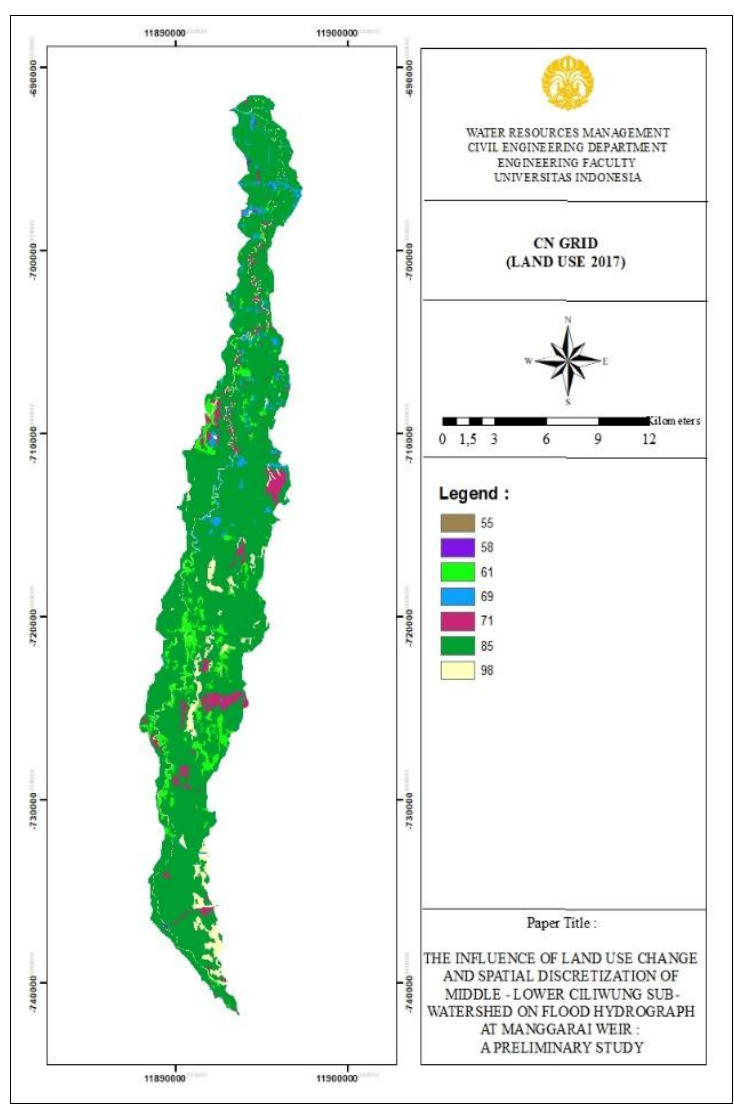

Fig. 4: CN Grid Map according to Land Use 2017

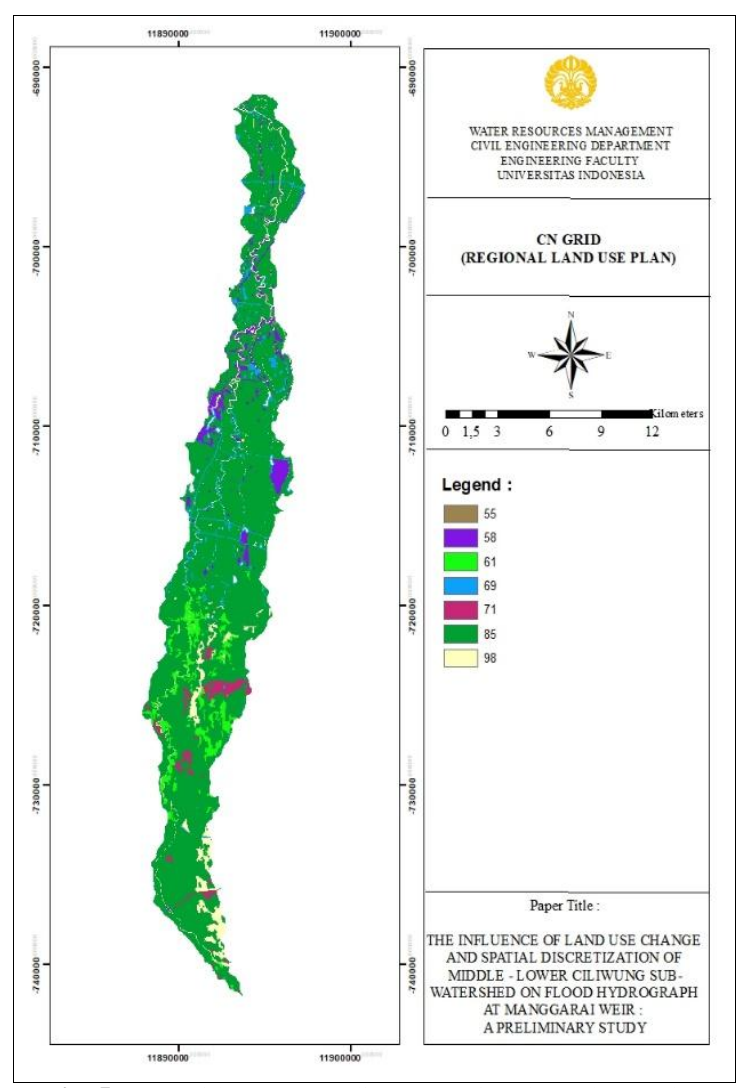

Fig. 5: CN Grid Map according to Regional Land Use Plan

\subsection{Average Rainfall Analysis}

The rainfall data used is rainfall data on Gadog, Cibinong, FTUI and Cawang rain stations in 2017. In this research the rainfall data used is the rainfall event data that generates the maximum discharge at Katulampa Dam, MT Haryono and Manggarai Weir in
2017, ie occurred on $13^{\text {th }}$ April 2017. However, since the discharge data at the AWLR downstream control point at Manggarai Weir in April 2017 is not recorded, the event rainfall data, the discharge data in Katulampa Dam and Manggarai Weir used are the data on the $15^{\text {th }}$ February 2017.

Table 3: Rainfall Data in $15^{\text {th }}$ February 2017

\begin{tabular}{|c|c|c|}
\hline Rain Station & Rainfall (mm) & Date \\
\hline Cawang & 24,50 & $15-$ Feb-17 \\
\hline FTUI & 27,80 & $15-$ Feb-17 \\
\hline Cibinong & 4,00 & $15-$ Feb-17 \\
\hline Gadog & 51,00 & $15-$ Feb-17 \\
\hline
\end{tabular}

Source: Meteorogical, Climatological, and Geophysical Agency, 2017

\subsection{Analyze the Distribution of Hourly Rainfall}

Due to limited hourly rainfall data then the distribution pattern on all rain stations follow the hourly rainfall distribution pattern at the FTUI Station on the date of the same event with the analysis time starting from $15^{\text {th }}$ February 2017 at $07: 00$ to $17^{\text {th }}$ February 2017 at 06:00. The selected rain duration uses an hourly rainfall distribution of 6 hours duration.

\subsection{Identify the Riparian Characteristics}

Since there is no secondary data source on the characteristics of riparian, the identification is based on survey with visual observation. As for the river profile data (cross section of each reach) using secondary data from BBWS Ciliwung Cisadane in 2012 (14).

\subsection{Inflow Hydrograph Analysis}

Because of the study location is in the middle to downstream of the Ciliwung watershed, it is necessary to inflow data from the Upper Ciliwung watershed. The inflow data was obtained from the data of water level at Katulampa Dam in 2017 which then put into the equation rating curve of Katulampa Dam (BBWSCC) as follows:

$\mathrm{Q}=41.307 \times(\mathrm{H}-0.094)^{2.02}$

Where:

Q : discharge in Katulampa Dam $\left(\mathrm{m}^{3} / \mathrm{s}\right)$

$\mathrm{H}$ : water level in Katulampa Dam (m)

\subsection{Outflow Hydrograph Analysis}

Every hydrological modeling requires observation data as a calibration and validation material to determine whether the modeling is in accordance with the conditions in the field or not. Therefore, it is necessary to outflow data as observation data at the control point downstream of the watershed analyzed. In this research, the downstream control point is located at the Manggarai Weir so that the Manggarai Weir data is needed at the same time as the analysis. However, since the record at the Manggarai Weir is only the water level and the Public Work Ministry has not published the rating curve equation at Manggarai Weir (after the addition of the water gate to the West Flood Canal), then to get the discharge at Manggarai Weir is calculated by river routing using Muskingum Method by using MT Haryono discharge data as an inflow.

$$
\begin{array}{ll}
\Delta \mathrm{x}=8,0 \mathrm{~km} & \mathrm{C}_{1}=\frac{\Delta \mathrm{t}-2 \mathrm{KX}}{2 \mathrm{~K}(1-\mathrm{X})+\Delta \mathrm{t}} \rightarrow \mathrm{C}_{1}=0,4246 \\
\mathrm{H}_{\text {freeboard }}=2,77 \mathrm{~m} & \mathrm{C}_{2}=\frac{\Delta \mathrm{t}+2 \mathrm{KX}}{2 \mathrm{~K}(1-\mathrm{X})+\Delta \mathrm{t}} \rightarrow \mathrm{C}_{2}=0,6548 \\
\mathrm{~g}=9,81 \mathrm{~m} / \mathrm{s}^{2} & \mathrm{C}_{3}=\frac{2 \mathrm{~K}(1-\mathrm{X})-\Delta \mathrm{t}}{2 \mathrm{~K}(1-\mathrm{X})+\Delta \mathrm{t}} \rightarrow \mathrm{C}_{3}=-0,0794
\end{array}
$$

$\mathrm{x} \quad=\quad 0,2$ 
$\Delta \mathrm{t} \quad=1 \mathrm{jam}$

Table 4: Result of River Routing at Manggarai Weir

\begin{tabular}{|c|c|c|c|c|c|}
\hline $\mathbf{t}$ & $\begin{array}{c}\text { Inflow MT } \\
\text { Haryono }\end{array}$ & $\mathbf{C}_{\mathbf{1}} \mathbf{I}_{\mathbf{j}+1}$ & $\mathbf{C}_{2} \mathbf{I}_{\mathbf{j}}$ & $\mathbf{C}_{3} \mathbf{Q}_{\mathbf{j}}$ & $\begin{array}{c}\text { Outflow } \\
\text { Manggarai }\end{array}$ \\
\hline (hour) & $\left(\mathrm{m}^{3} / \mathrm{s}\right)$ & 0,4246 & 0,6548 & $-0,0794$ & $\left(\mathrm{~m}^{3} / \mathrm{s}\right)$ \\
\hline 0 & 0,00 & & & & 0,00 \\
\hline 1 & 40,17 & 17,06 & 0,00 & 0,00 & 40,17 \\
\hline 2 & 41,92 & 17,80 & 26,30 & $-3,19$ & 40,91 \\
\hline 3 & 46,45 & 19,72 & 27,45 & $-3,25$ & 43,92 \\
\hline 4 & 48,80 & 20,72 & 30,41 & $-3,49$ & 47,65 \\
\hline 5 & 53,66 & 22,78 & 31,95 & $-3,78$ & 50,95 \\
\hline 6 & 61,35 & 26,05 & 35,13 & $-4,05$ & 57,14 \\
\hline 7 & 66,75 & 28,35 & 40,17 & $-4,54$ & 63,98 \\
\hline 8 & 72,37 & 30,73 & 43,71 & $-5,08$ & 69,36 \\
\hline 9 & 72,94 & 30,97 & 47,39 & $-5,51$ & 72,85 \\
\hline 10 & 71,23 & 30,25 & 47,76 & $-5,79$ & 72,22 \\
\hline 11 & 68,14 & 28,93 & 46,64 & $-5,74$ & 69,84 \\
\hline 12 & 66,75 & 28,35 & 44,62 & $-5,55$ & 67,41 \\
\hline 13 & 61,35 & 26,05 & 43,71 & $-5,36$ & 64,41 \\
\hline 14 & 60,30 & 25,61 & 40,17 & $-5,12$ & 60,66 \\
\hline 15 & 69,53 & 29,53 & 39,48 & $-4,82$ & 64,19 \\
\hline 16 & 81,19 & 34,48 & 45,53 & $-5,10$ & 74,91 \\
\hline 17 & 93,71 & 39,79 & 53,16 & $-5,95$ & 87,01 \\
\hline 18 & 100,28 & 42,58 & 61,36 & $-6,91$ & 97,03 \\
\hline 19 & 110,53 & 46,94 & 65,66 & $-7,71$ & 104,89 \\
\hline 20 & 117,63 & 49,95 & 72,37 & $-8,33$ & 113,99 \\
\hline 21 & 121,26 & 51,49 & 77,02 & $-9,06$ & 119,46 \\
\hline 22 & 123,09 & 52,27 & 79,40 & $-9,49$ & 122,18 \\
\hline 23 & 121,26 & 51,49 & 80,60 & $-9,71$ & 122,38 \\
\hline 24 & 117,63 & 49,95 & 79,40 & $-9,72$ & 119,63 \\
\hline 25 & 110,53 & 46,94 & 77,02 & $-9,50$ & 114,46 \\
\hline 26 & 103,64 & 44,01 & 72,37 & $-9,09$ & 107,29 \\
\hline 27 & 93,71 & 39,79 & 67,86 & $-8,52$ & 99,13 \\
\hline 28 & 87,34 & 37,09 & 61,36 & $-7,87$ & 90,57 \\
\hline 29 & 81,19 & 34,48 & 57,19 & $-7,19$ & 84,48 \\
\hline 30 & 72,37 & 30,73 & 53,16 & $-6,71$ & 77,19 \\
\hline 31 & 66,75 & 28,35 & 47,39 & $-6,13$ & 69,60 \\
\hline 32 & 61,35 & 26,05 & 43,71 & $-5,53$ & 64,23 \\
\hline 33 & 58,73 & 24,94 & 40,17 & $-5,10$ & 60,01 \\
\hline 34 & 56,17 & 23,85 & 38,46 & $-4,77$ & 57,54 \\
\hline 35 & 53,66 & 22,78 & 36,78 & $-4,57$ & 54,99 \\
\hline 36 & 51,20 & 21,74 & 35,13 & $-4,37$ & 52,51 \\
\hline 37 & 50,23 & 21,33 & 33,52 & $-4,17$ & 50,68 \\
\hline 38 & 51,69 & 21,95 & 32,89 & $-4,03$ & 50,81 \\
\hline 39 & 53,16 & 22,57 & 33,84 & $-4,04$ & 52,38 \\
\hline 40 & 54,15 & 23,00 & 34,81 & $-4,16$ & 53,64 \\
\hline 41 & 56,17 & 23,85 & 35,46 & $-4,26$ & 55,05 \\
\hline 42 & 58,73 & 24,94 & 36,78 & $-4,37$ & 57,35 \\
\hline 43 & 61,35 & 26,05 & 38,46 & $-4,56$ & 59,96 \\
\hline 44 & 62,68 & 26,62 & 40,17 & $-4,76$ & 62,03 \\
\hline 45 & 64,03 & 27,19 & 41,04 & $-4,93$ & 63,30 \\
\hline 46 & 64,03 & 27,19 & 41,92 & $-5,03$ & 64,08 \\
\hline 47 & 62,68 & 26,62 & 41,92 & $-5,09$ & 63,45 \\
\hline 48 & 61,62 & 26,17 & 41,04 & $-5,04$ & 62,17 \\
\hline
\end{tabular}

\subsection{HEC-GeoHMS Modeling}

By using HEC-GeoHMS there are several methods to be determined. The Basin Model consists of Loss Method, Transform Method, and Baseflow Method for Subbasin parameters and Route Methods for River parameters. In this research the method used is SCS method for Loss and Transform Method on Subbasin and Kinematic Wave for Route Method on River. Determination of the accuracy of the model will use the Nash-Sutcliffe Efficiency (NSE) coefficient method.

Data processing using HEC-GeoHMS model is divided into 3 parts, namely :

\section{Terrain Preprocessing}

In this process DEM, as field data, is used as input to obtain an additional dataset that illustrates the drainage pattern within the watershed and allows for flow delineation.

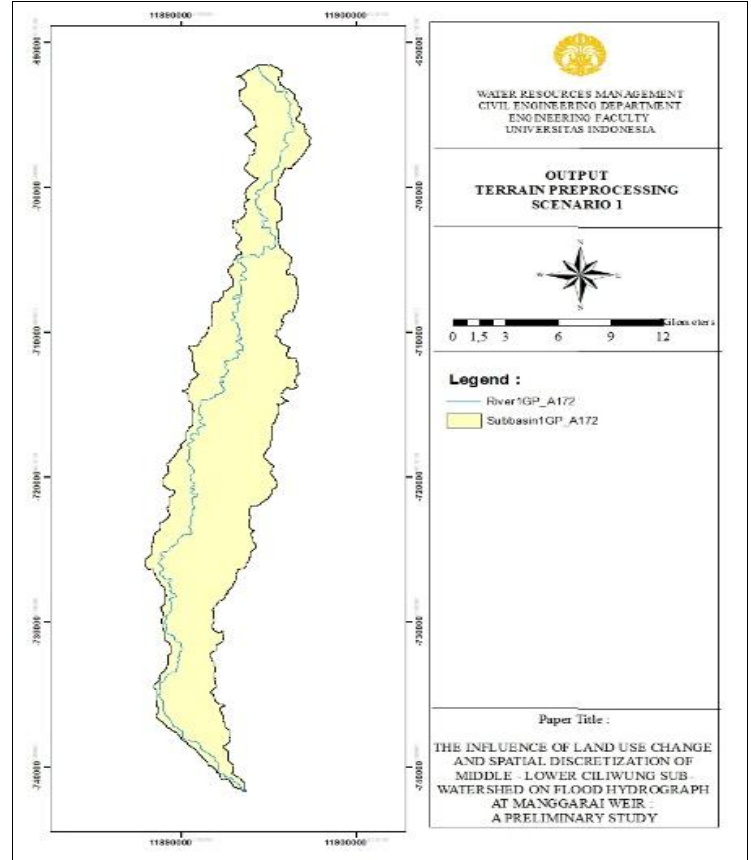

Fig. 5: Output Terrain Preprocessing Scenario 1

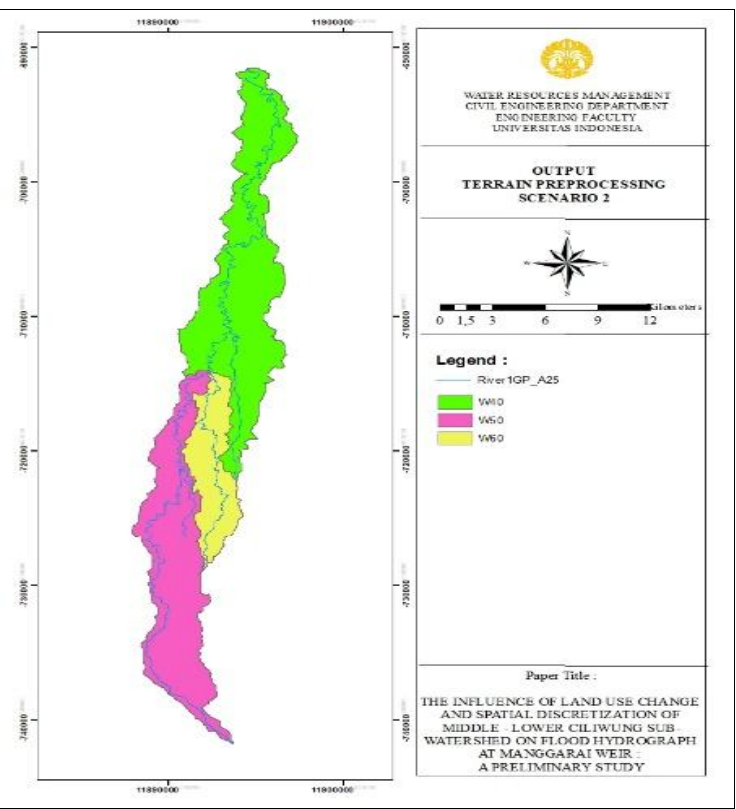

Fig. 6: Output Terrain Preprocessing Scenario 2

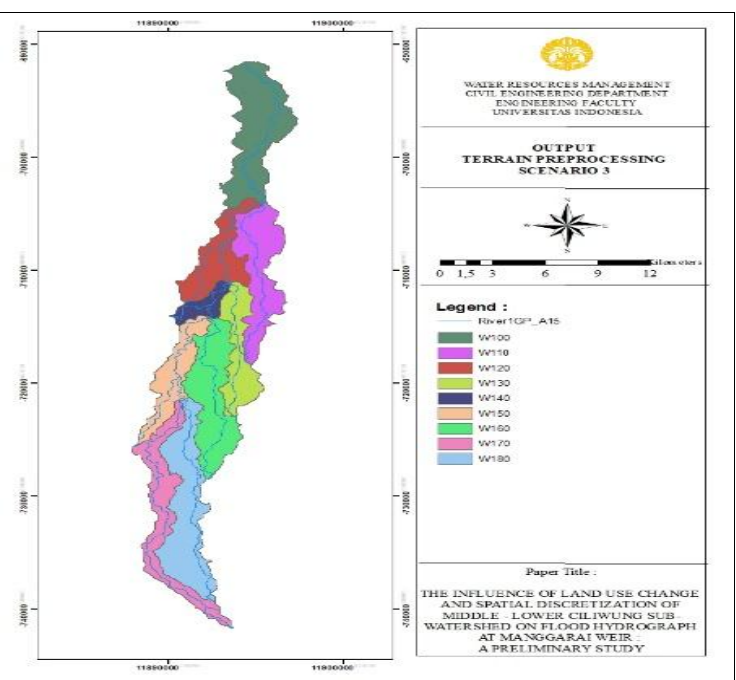

Fig. 7: Output Terrain Preprocessing Scenario 3 


\section{Basin Processing}

After the Terrain Preprocessing and project area have been defined, the Stream and Subbasin Characteristic can be done. The parameters obtained from spatial data processing are: River Profile, River Length, River Slope, Basin Slope, Longest Flowpath, Basin Centroid, Centroid Elevation, Centroidal Flowpath.

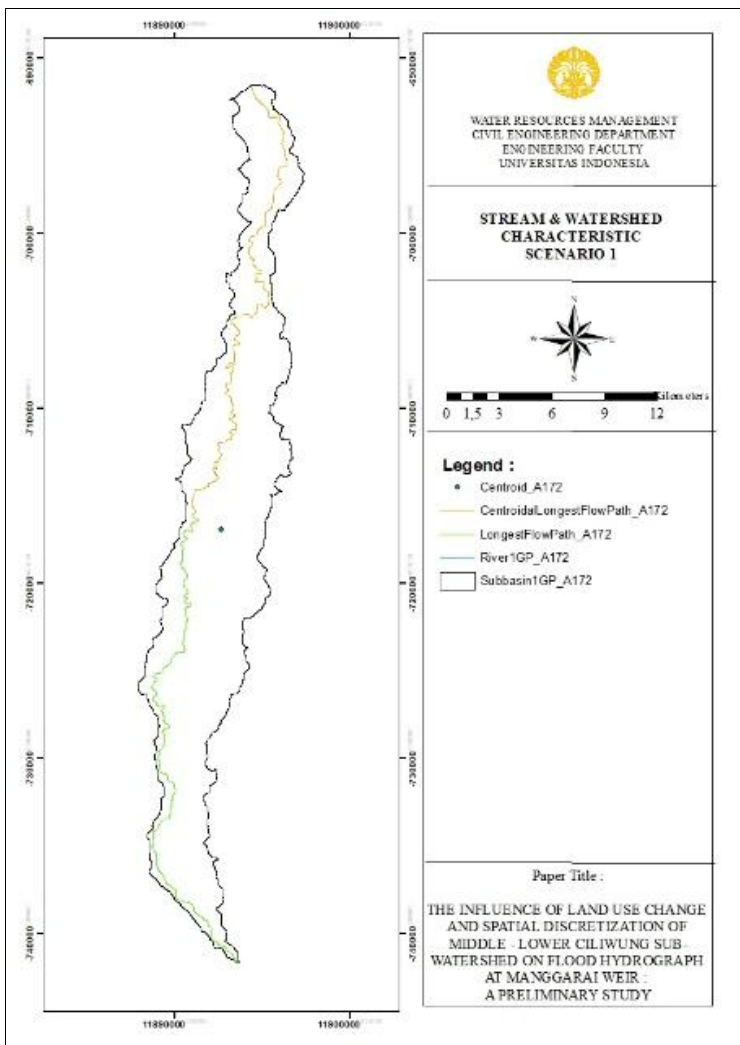

Fig. 8: Output Basin Processing Scenario 1

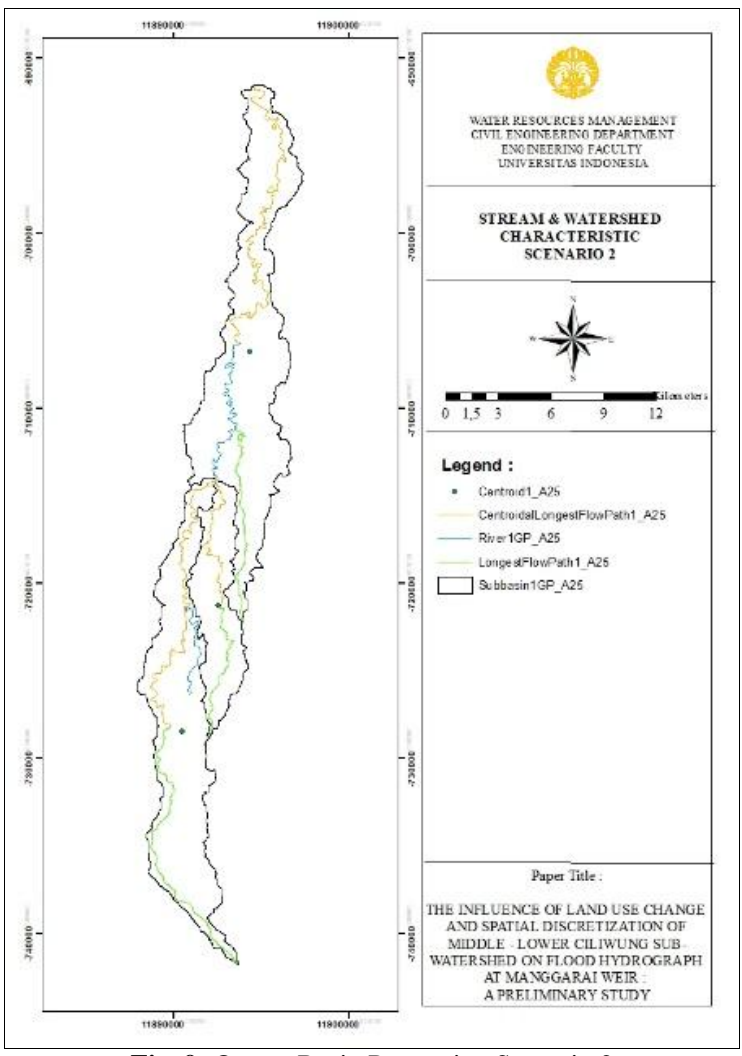

Fig. 9: Output Basin Processing Scenario 2

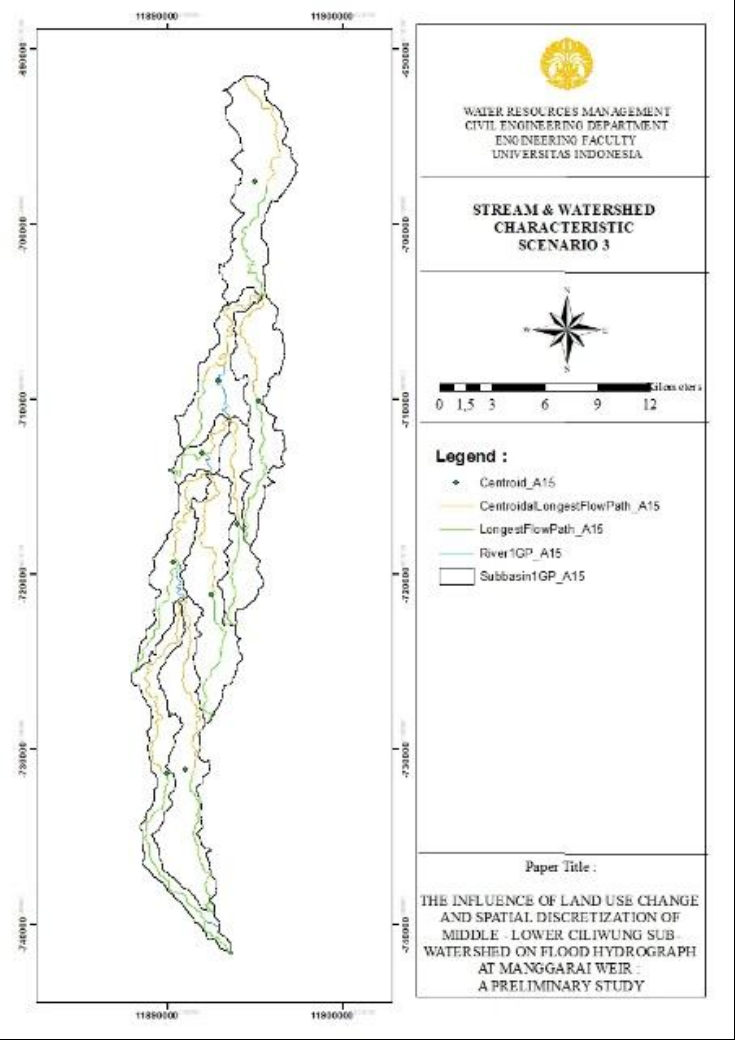

Fig. 10: Output Basin Processing Scenario 3

\section{Modeling HEC-HMS}

The parameters required to run the HEC-HMS model have been filled, including the basin model and meteorologic model. In the Loss Method Basin parameter, there are input data for initial abstraction, curve number and impervious. In the Transform Method Basin parameter, there is a data lag time input. Each input data is filled automatically from the results of the previously processed HEC-GeoHMS data import. In the Meteorology Model parameter, there is a precipitation data input with the method chosen is Specified Hyetograph. In Time-Series Data parameters, the parameters of the precipitation data to be input must be determined. In this study, precipitation data incremental milimeters were selected with 1 hour data intervals.

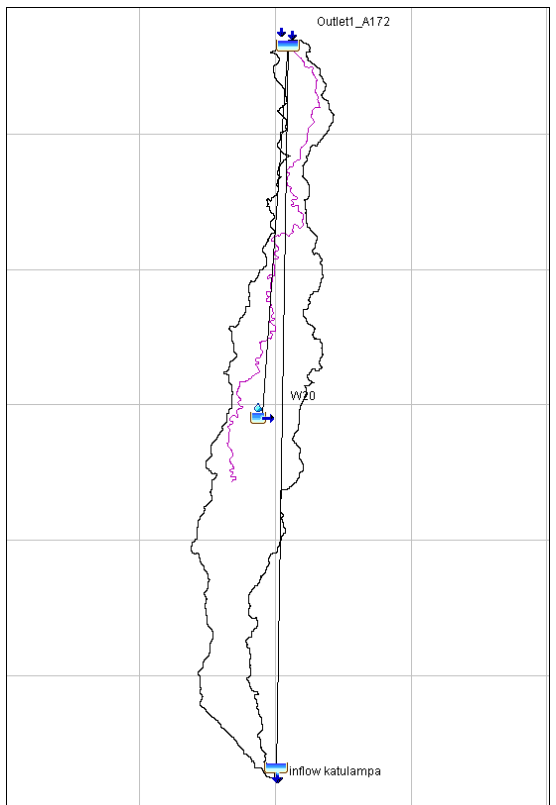

Fig. 11: Basin Model on HEC-HMS Scenario 1 


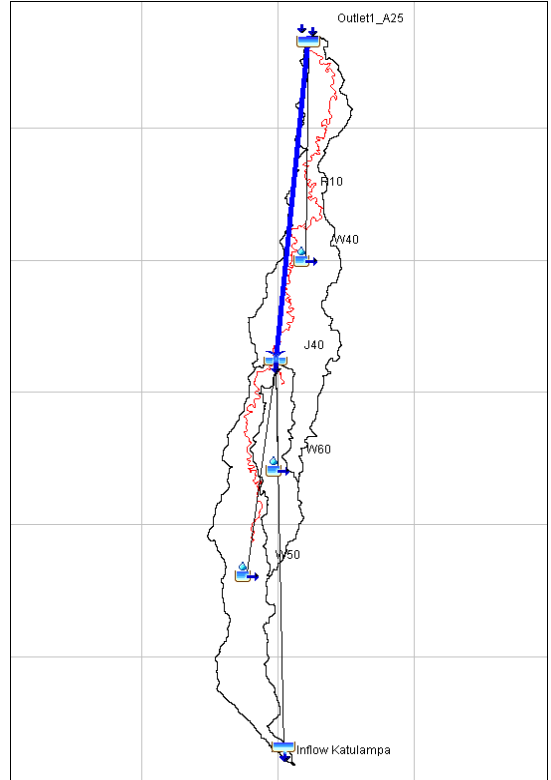

Fig. 12: Basin Model on HEC-HMS Scenario 2

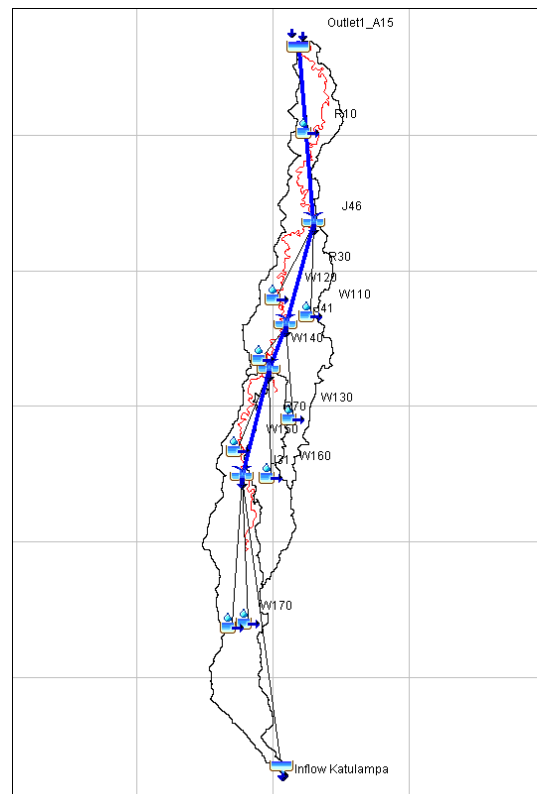

Fig. 13: Basin Model on HEC-HMS Scenario 3

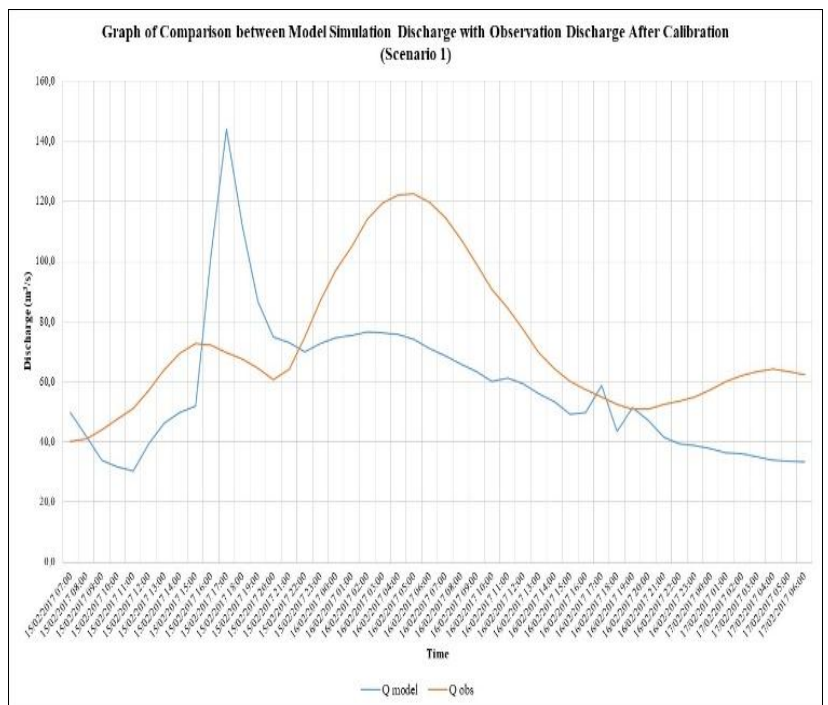

Fig. 14: Graph of Comparison between Model Simulation Discharge with Observation Discharge Scenario 1

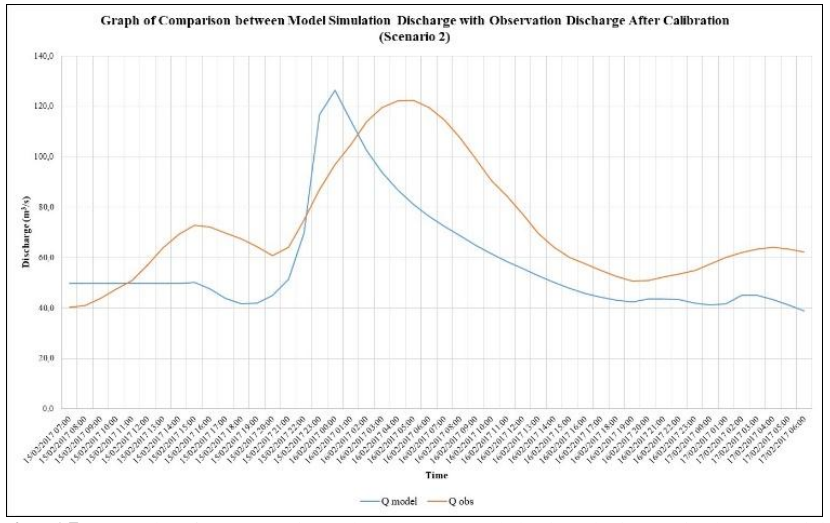

Fig. 15: Graph of Comparison between Model Simulation Discharge with Observation Discharge Scenario 2

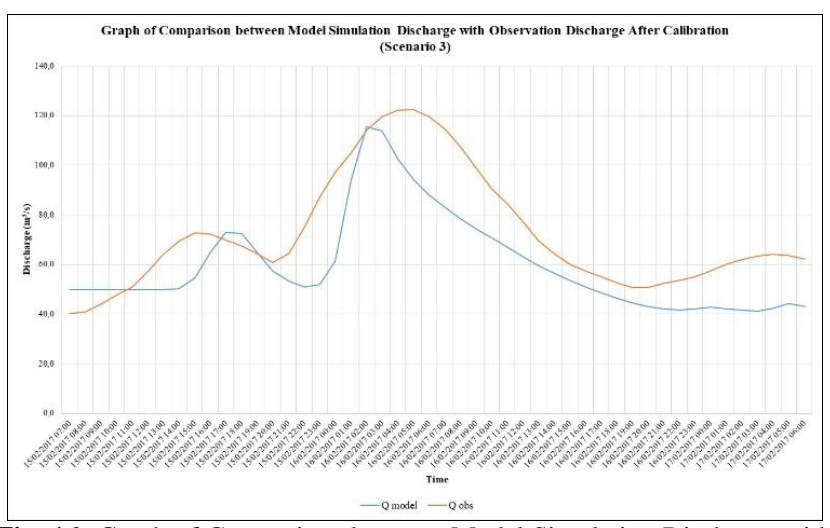

Fig. 16: Graph of Comparison between Model Simulation Discharge with Observation Discharge Scenario 3

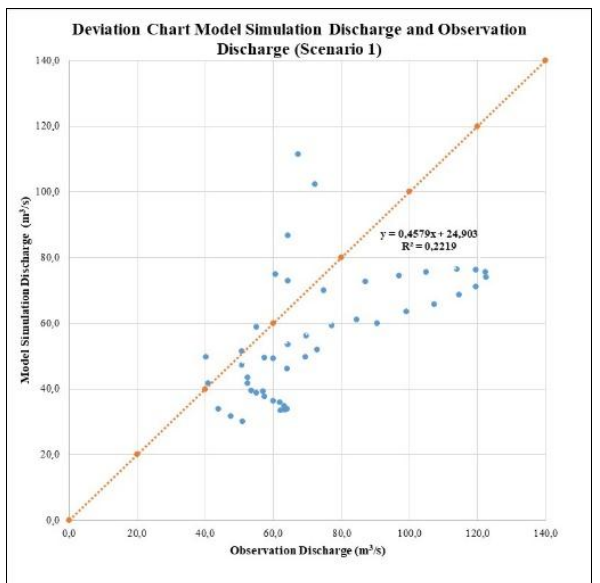

Fig. 17: Deviation Chart Model Simulation Discharge and Observation Discharge Scenario 1

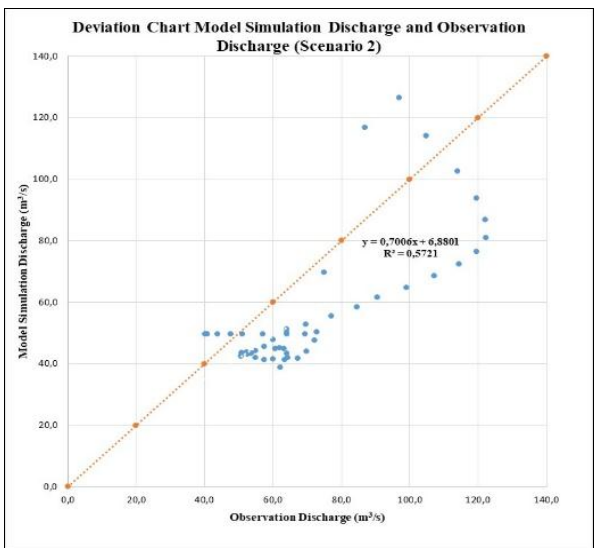

Fig. 18: Deviation Chart Model Simulation Discharge and Observation Discharge Scenario 2 


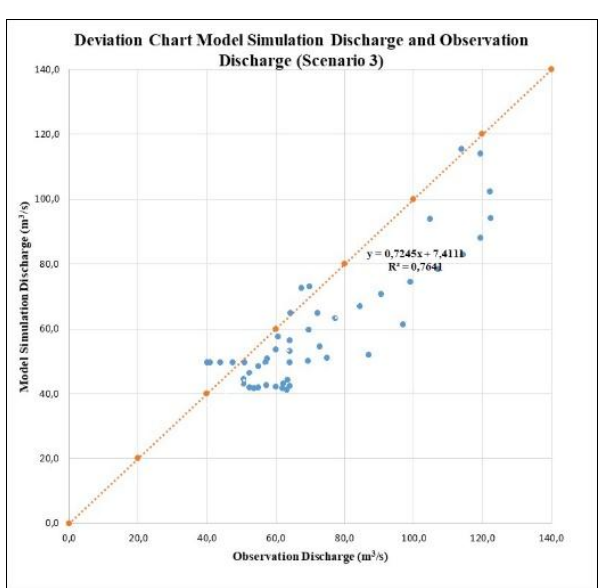

Fig. 19: Deviation Chart Model Simulation Discharge and Observation Discharge Scenario 3

Based on the results of the analysis using the 3 scenarios above, it can be made a graph of flood hydrograph comparison recapitulation of the simulation and calibration results and the recapitulation graph of the deviation recapitulation of the simulation discharge and observation discharge as follows:

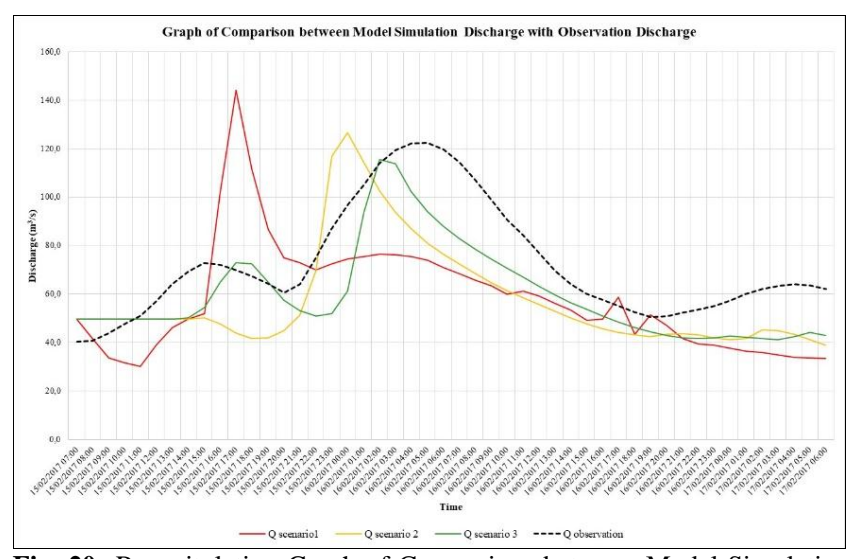

Fig. 20: Recapitulation Graph of Comparison between Model Simulation Discharge with Observation Discharge for Scenario 1, 2 and 3

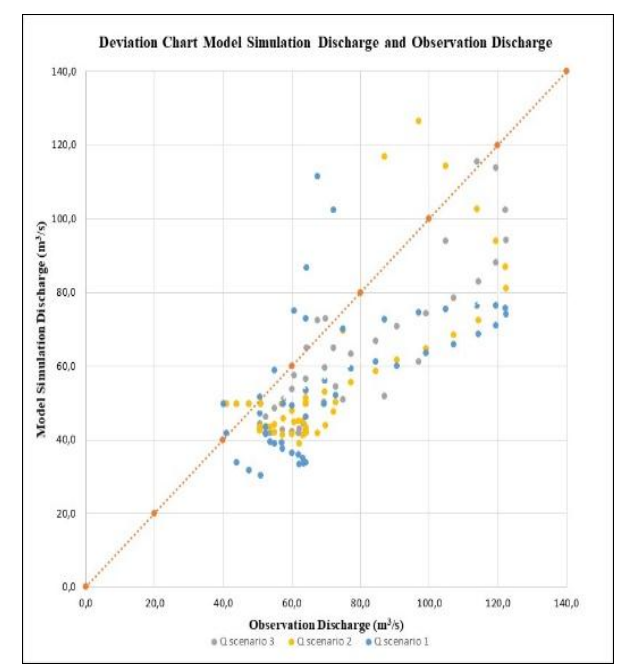

Fig. 21: Deviation Chart Model Simulation Discharge and Observation Discharge for Scenario 1, 2 and 3

Based on the graph above, can be given an explanation as follows:

1. The cause of a relatively large deviation value

Of the three scenarios, there is still a relatively large bias value. This is because:

a. Determination of value on the parameter of sub watershed (Loss and Transform Method)
- In this study only 4 rain stations were used in the Middle Ciliwung Sub Watershed to Manggarai Weir, namely Cawang Station, FTUI Station, Cibinong Station and Gadog Station. Whereas in that location has many rain stations in it. However, the four stations were chosen because only the four rain stations have complete data in the year to be analyzed. Limitations of rain stations used can cause the calculation of precipitation of the area obtained less represent the actual rainfall. Although the rain stations are in the same basin there is a possibility that not all areas in the watershed experience rain.

- Due to the limitations of existing data, the distribution of rain used is considered the same for all rain stations used in this study. It is probable that each rain-affected sub watershed has a different rainfall distribution than the other sub watersheds.

- The determination of $\mathrm{CN}$ values has many factors of inaccuracies. One factor is the definition of different land use conditions between individuals.

b. Determination of value on parameter Reach (Route Method)

- Due to data limitations, determining the roughness coefficient (n) Manning is only through visual observation, without measurement in the field it is necessary to navigate the river to get more accurate riparian characteristics data.

- The shape and dimensions of the channel/river are considered the same as long as the reach is analyzed.

2. Comparison between the three alternative scenarios

a. The more detailed the spatial discretization of the sub watershed, the more it decreases the peak flood discharge and extends the peak flood time.

b. The more detailed the spatial discretization of sub watershed, the simulation result is closer to observation data both in terms of value and pattern.

c. The more detailed the spatial discretization, the more delineated sub watersheds and the more reaches being analyzed, the smaller the expanse and the detailed characteristics of the observed riparian that may affect the coefficient value of the channel roughness (n Manning).

Furthermore, it is determined which alternative scenarios will be chosen to analyze the flood hydrograph prediction by referring to the Regional Land Use Plan map, the recapitulation is as follows:

Table 5: Recapitulation of Model Simulation and Calibration Results

\begin{tabular}{|c|l|c|c|c|}
\hline \multirow{2}{*}{ No } & \multicolumn{1}{|c|}{ Description } & \multicolumn{3}{c|}{ Scenario } \\
\cline { 3 - 5 } & & $\mathbf{1}$ & $\mathbf{2}$ & $\mathbf{3}$ \\
\hline 1 & Stream threshold area $\left(\mathrm{km}^{2}\right)$ & 174,39 & 25 & 15 \\
\hline 2 & Amount of sub watershed & 1 & 3 & 9 \\
\hline 3 & NSE model & $-0,925$ & $-0,185$ & 0,018 \\
\hline 4 & NSE after CN calibration & $-0,476$ & $-0,182$ & 0,135 \\
\hline 5 & NSE after IA calibration & $-0,425$ & $-0,182$ & 0,137 \\
\hline 6 & NSE after Lag Time calibration & $-0,413$ & 0,136 & 0,375 \\
\hline 7 & NSE after n Manning calibration & - & 0,136 & 0,469 \\
\hline 8 & Qp & 142,80 & 142,5 & 135,6 \\
\hline 9 & $\mathrm{Qp}_{\text {observation }}$ & 122,40 & 122,40 & 122,40 \\
\hline 10 & $\mathrm{Qp}_{\text {kalibrasi }}$ & 144,00 & 126,5 & 115,5 \\
\hline 11 & $\mathrm{R}^{2} \mathrm{Q}_{\text {obs }}$ vs $\mathrm{Q}_{\text {model }}$ & 0,222 & 0,572 & 0,764 \\
\hline
\end{tabular}

From the recapitulation table above, it can be concluded that after calibration, scenario 3 has an efficiency value of $0.764(\mathrm{E} \sim 1)$ it can be concluded that it is closer to the observation data. So that for the next alternative spatial discretization and riparian characteristics in scenario 3 will be used to analyze the flood hydrograph prediction at Manggarai Weir by using land use maps which refer to the Regional Land Use Plan Map at Bogor Regency, Bogor City, Depok City and DKI Jakarta Province.

\subsection{Hydrograph Flood Prediction according to Re- gional Land Use Plan Map}

To plan the flood discharge, it is necessary to calculate in advance the rainfall plan where in this case the rainfall data will be used 
based on data from 4 rain stations (Cawang, FTUI, Cibinong, Gadog) for the last 10 years $(2008$ - 2017). By calculating the frequency distribution parameters for each rain station data, then can be calculated rainfall plan with Gumbel Method.

Table 6: Rainfall Plan

\begin{tabular}{|c|c|c|c|c|}
\hline \multirow{2}{*}{ Return Period } & \multicolumn{4}{|c|}{ Rain Station } \\
\cline { 2 - 5 } & Cawang & FTUI & Cibinong & Gadog \\
\hline 2 & 121,41 & 121,39 & 88,50 & 116,07 \\
\hline 5 & 159,30 & 146,20 & 115,86 & 150,77 \\
\hline 10 & 184,40 & 162,63 & 133,98 & 173,75 \\
\hline 25 & 216,10 & 183,38 & 156,87 & 202,78 \\
\hline 50 & 239,62 & 198,78 & 173,85 & 224,32 \\
\hline 100 & 262,97 & 214,07 & 190,71 & 245,70 \\
\hline
\end{tabular}

By performing the same stages in the HEC-GeoHMS modeling, namely through Terrain Preprocessing, Basin Processing and Modeling HEC-HMS stages, and with reference to scenario 3, the flood hydrograph is obtained with a 2, 5 and 10 year return period for the Regional Land Use Plan map as follows :

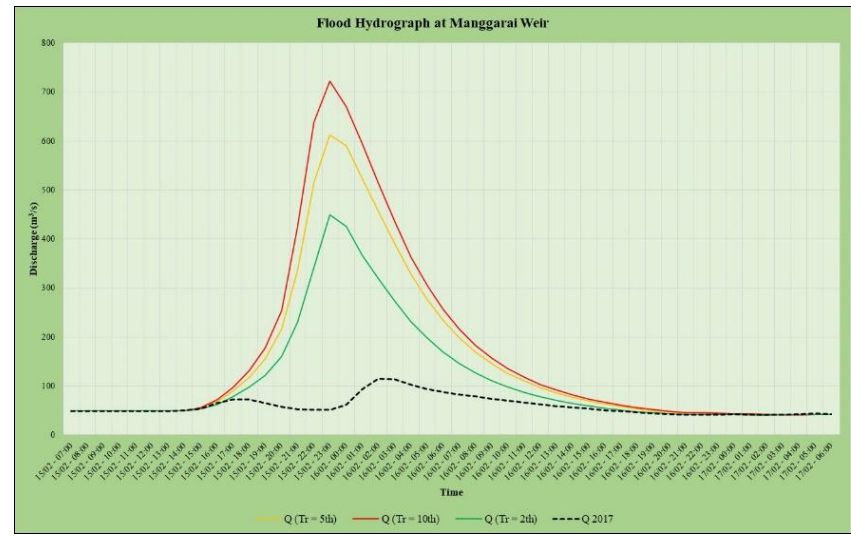

Fig. 22: Flood Hydrograph at Manggarai Weir

Based on the graph of the results of the flood hydrograph prediction simulation with various return periods above, flood hydrograph 2017 has a peak discharge smaller than the peak discharge with a 2 years, 5 years and 10 years. Likewise with peak time, peak time for flood discharge with a return period of 2 years, 5 years and 10 years is faster than the peak time of 2017 and now. This is because the rainfall data inputted in 2017 is the event rainfall data, while for the peak discharge of 2 years, 5 years and 10 years, the rainfall is planned from the maximum rainfall data during the last 10 years. Rainfall event data used is rainfall data on $15^{\text {th }}$ February 2017, where on that date rainfall in Cawang, FTUI, Cibinong and Gadog Stations was not too high (see Table 3) causing differences in peak discharge in 2017 with peak discharge based on return period 2 years, 5 years and 10 years far enough.

\section{Conclusion}

Conclusions from this research, among others:

1. The more detailed the spatial discretization, the more delineated sub watersheds and the more reaches being analyzed, the smaller the expanse and the detailed characteristics of the observed riparian that may affect the coefficient value of the channel roughness ( $\mathrm{n}$ Manning). Therefore, the smaller the spatial discretization of the sub watershed, the lower the peak discharge of floods and extend the peak flood time. Qp scenario 1 is $144 \mathrm{~m}^{3} / \mathrm{s}$, Qp scenario 2 is $126.5 \mathrm{~m}^{3} / \mathrm{s}$ and Qp scenario 3 is $115.5 \mathrm{~m}^{3} / \mathrm{s}$.

2. Based on the simulation result using Scenario 3 and Regional Land Use Plan Map, we get the prediction of peak discharge as follows:

Discharge in $2017=115.5 \mathrm{~m}^{3} / \mathrm{s}$

Current discharge $=130.8 \mathrm{~m}^{3} / \mathrm{s}$
Discharge in 2 years return period $=449,3 \mathrm{~m}^{3} / \mathrm{s}$ Discharge in 5 years return period $=612,7 \mathrm{~m}^{3} / \mathrm{s}$

Discharge in 10 years return period $=722,6 \mathrm{~m}^{3} / \mathrm{s}$

\section{Acknowledgement}

Nonik Eko Wahyuning Tiyas expresses her appreciation as her study was conducted by the research funding from Indexed International Publication Program for Thesis 2018 or Hibah Publikasi Internasional Terindeks Untuk Tugas Akhir 2018 (PITTA 2018) in Universitas Indonesia, with Contract No. 2423/UN2.R3.1/HKP.05.00/2018.

\section{References}

[1] NEDECO, Masterplan for Drainage and Flood Control of Jakarta, Jakarta: Ministry of Public Works and Electric Power, Directorate General of Water Resources Development, 1973.

[2] M. Ali, S. Hadi and B. Sulistyantara, "Study on Land Cover Change of Ciliwung Downstream Watershed with Spatial Dynamic Approach," Science DIrect, 2016.

[3] C. Asdak, Hidrologi Dan Pengelolaan Daerah Aliran Sungai, Yogjakarta: Gajah Mada University Press, 2002.

[4] S. Irianto, Kajian Hidrologi Daerah Aliran Sungai menggunakan Model HEC-1 [Thesis], Bogor: Institut Pertanian Bogor, 2000.

[5] H. Pawitan, Perubahan Penggunaan Lahan dan Pengaruhnya terhadap Hidrologi Daerah Aliran Sungai, Bogor: Laboratorium Hidrometeorologi FMIPA-IPB, 2004.

[6] BPDAS, Monitoring dan Evaluasi DAS Ciliwung untuk Pengendalian Banjir, Bogor: BPDAS Ciliwung Citarum, 2007.

[7] W. Y. Bhakti, Prediction Of Potential Erotion Rate And Potential Waste Generation Rate Based On Impervious Land Cover Using Geographic Information System (GIS) - Case Study Ciliwung Watershed, Depok, 2015.

[8] V. P. Singh and D. A. Woolhiser, "Mathematical Modelling of Watershed Hydrology," Journal of Hydrologyc Engineering, pp. 270-292, 2002

[9] M. J. Fleming and J. H. Doan, HEC-GeoHMS Geospatial Hydrologic Modeling Extension Version 10.1, California: US Army Corps of Engineers, 2003.

[10] Wanny K, dkk, "Pola Hujan Provinsi Jawa Barat," 2003.

[11] B. Triatmodjo, Hidrologi Terapan, Yogyakarta: Jurusan Teknik Sipil Fakultas Teknik Universitas Gajah Mada, 2008. C. D. Soemarto, Hidrologi Teknik, Jakarta: Erlangga, 1999.

[12] V. T. C. Open Channel Hydraulics, USA: McGraw-Hill, 1988

[13] P. P. N. S. Studi Penataan Ulang Daerah Sempadan Sungai CIliwung, Jakarta: BBWSCC, Dirjen Sumber Daya Air, Kementerian PUPR, 2012. 